\title{
HOW TO MOTIVATE ETHNIC MINORITY STUDENTS IN SECONDARY AND HIGH SCHOOLS IN DISADVANTAGED NORTHWEST AREA OF VIETNAM TO LEARN ENGLISH EFFECTIVELY
}

\section{Huong Van Vi}

Article History

Received: June 5, 2019

Accepted: August 29, 2019

Published: September 30, 2019

\section{Keywords}

Motivation, rural students, mountainous students, English, effectively, Vietnam
Tay Bac University, Vietnam

Email: huongblackt@gmail.com

\section{INTRODUCTION}

Ethnic minority students in the Northwest of Vietnam are defined as the people who are from different ethnic groups such as Thai, H'Mong, Tay, Nung, Dao. They live and study in the rural and mountainous disadvantaged areas, in small villages with the low living standard and lack awareness of society. Going to school has always been a big challenge for them as they need to travel very long distances in small and dangerous paths, through high mountain ranges, crossing deep streams and rivers, and facing with various severe weather conditions and natural disasters, ranging from freezing weather in the winter, landslide and floods in the rainy season. In addition, learning in the poorly-equipped schools (for instance, many rural schools are still made of bamboos and wood without electricity and other modern equipment) has also erased their learning motivation and ambition. Moreover, the lack of awareness of the crucial role of education among their parents and themselves also discourages students from learning, especially with English, which has been considered one of the most difficult subjects for rural students.

The significant role of English in all aspects of social life has been clearly defined recently, especially in the globalisation era where international collaboration is the key to ensure the sustainable development of each country. With proficiency in English, the national human capital will be strengthened, which would enhance Vietnam's competitiveness in the international economic and political arena. Understanding the power of foreign languages, especially English, the Ministry of Education and Training has introduced English as a compulsory subject from grade 3 since 2012 in the national education system in Vietnam. Remarkably, on the September $30^{\text {th }}$, 2008 the Prime Minister of Vietnam issued the Decision No 1400/QD-TTg on approving the plan for "Teaching and Learning Foreign Language in the National Education System in the period of 2008-2020". Despite these efforts, the quality of teaching and learning English in disadvantaged, rural and mountainous schools still falls short of expectations.

The solutions for the abovementioned problems require time and the efforts of the government, the Ministry of Education and Training, the community and whole society. As one of the main causes of the low quality of learning English in rural schools is the lack of motivation, this research focuses on proposing some solutions to motivate ethnic minority students in the Northwest of Vietnam to study English effectively.

\section{LITERATURE REVIEW}

Motivation in learning is the internal power of students which help them to focus on learning and devoting their time, energy and knowledge to their ambitions and dreams. There have been a number of studies on clarifying the role of motivation in achieving the learning goals, the classifications of motivation, and how to create and maintain learning motivation. In 1972, the research on the attitudes and motivation in learning foreign languages by Gardner, R. C. \& Lambert, W. (1972) clearly demonstrates the key roles of these two factors in the learning results and objectives. These researchers also state that the quality and result of learning foreign languages not only base on the 
aptitudes of students, but also on their motivation. The two different kinds of motivation are clearly analysed by Richard, M. R. and Deci, E. L. (2000) namely extrinsic motivation and intrinsic motivation. The two authors also highlight the new research direction about learners' motivation.

A lot of studies on the key factors influencing students' motivation and the crucial roles of teachers in creating and maintaining learners' motivation have been conducted. Researchers have been focusing on clarifying the key roles of English teachers in English teaching process and how teachers can inspire students to effectively learn English. Dörnyei, Z. (2001) have highlighted the relationship between learning motivation and the learners' confidence, the great influences and benefits of motivation on students' learning outcome and quality of learning. He also suggests some methods and techniques to motivate students to learn foreign languages.

In Vietnam, the significant role of motivation and the techniques to motivate students to learn have been studied and clarified. However, there is very limited number of researchers and studies in this field while the published works have not fully reflected the various characteristics of creating the learning motivation for the learners. The research by Pham, T. T. H. (2010) mentions different kinds of learners' motivation. She also clarifies the key factors which have great influence on how students learn. Moreover, the learners' attitudes and motivation in learning English writing skill have also been analysed and what demotivate students in learning has been revealed.

However, there is no research about how to create and maintain motivation to learn English for ethnic minority students in the Northwest of Vietnam.

\section{RESEARCH METHODS AND RESULTS}

\subsection{Research methods}

- Theoretical research methods: This research is based on different reliable sources of information such as peer reviewed articles, published books and other documents which related to the topic of motivating students to learn English. Through reading, summarising, collecting, analysing and criticising, the methods to inspire students to learn has been outlined and the most common factors to create and maintain learning motivation have also been proposed.

- Practical research methods: Studying the specific difficulties of ethnic minority students in their English learning process; studying the key factors leading to the demotivation of students and the core factors to help learners maintain learning motivation.

\subsection{Research results}

\subsubsection{Roles of motivation in English learning and teaching}

Motivation in foreign language learning is known as the combination of "efforts, desires, and attitudes" in the learning process to fulfill the learning objectives (Adara, R. A., 2018). Motivation is one of the fundamental factors in learning a language as learners' positive feelings and excitement in learning a second language can improve learning outcomes (Hamidah et al, 2017). Motivation has a great influence on how students learn foreign languages as the primary drive in foreign language learning and maintaining learners' interest during their tedious and challenging learning journey. With a proper learning motivation, students can master their target language regardless of their language aptitude and learning conditions (Gardner, R. C. \& Lambert, W., 1972). Thus, many teachers believe that motivation is the key factor for success in learning English with "a curial role in students' performance, achievement and engagement" (Pinar, Y. K. \& Kurt, H., 2018). With proper and sufficient learning motivation, students can overcome difficulties with different solutions and try their best to learn the language better.

It is important to know different kinds of motivation to help teachers and educator focus on the right types of motivation for different purposes, in different context and circumstances. Gardner, R. C. \& Lambert, W. (1972) suggest two kinds of motivation namely Integrative motivation and Instrumental motivation. While integrative motivation is defined as the desire to integrate oneself in the target culture, the instrumental motivation in language learning is characterised with specific and clear purpose such as to acquire the target language to communicate with people in their job, in the community. Therefore, in case students do have sufficient time for using and experiencing real English in a English native English speaking community, the instrumental motivation should be paid more attention (Dörnyei, Z. \& Ottó, I., 1998). From another perspective, motivation is classified into Extrinsic and Intrinsic Motivation. Extrinsic motivation is the desire to learn the language to engage in external social activities, while intrinsic motivation is the desire to engage in learning activities to boost internal self-confidence. The understanding of different kinds of motivation has a significant role as it will help teachers reorganise the English classes and activities to best suit their students' levels. 


\subsubsection{How to create and maintain motivation for ethnic minorities students to learn English}

Firstly, setting examples: The beginning of each school year will always be the most suitable time for each rural school to organize meetings between students and one or two successful local people who have received some significant success thanks to being competent in English. These people should be the one who lives in the same area with the students or the person who come from the same background, same ethnic group to ensure that ethnic minorities students see the similarities. The chosen content of the meetings should be about the crucial role of English in this modern life, in the time of globalisation, especially how it relates to the development of local community and students' future careers. It is important to stress on how this language generates plenty of opportunities to get a highpaid job in the future, even in the sectors such as service and tourism. More importantly, the meetings should also focus on how these people manage their time, finance and work to study English well. In addition, the sharing about their English learning process will be useful for students to learn from and apply some suitable approaches and techniques to their learning process. Therefore, the guests should create a friendly and warm atmosphere by asking simple questions to know more about students, to understand their thinking and their difficulties in learning English so that they can direct the sharing sessions accordingly.

Through the sincere sharing and interactions, ethnic minorities students can strengthen their belief in learning English for different purposes. Moreover, they will be inspired by the guests through the way they learn English, the way they think about their future in order to generate energy and strong determination to study the language. Once their attitude towards learning English is positive, they would take action to learn English effectively for their own purpose. They will put more effort to fulfill their own ambitions and inspiration. The better result will come if students are motivated to believe in learning, believe in themselves and their bright future.

Secondly, building an attractive learning environment: The lack of technological supports and basic facilities poor condition of classrooms can be the challenges to reduce the motivation in each rural student to learn English and as a result, they become pessimistic and blame the circumstances. Therefore, the learning environment should be handled to inspire and motivate students to learn English.

What is happening in English classes in rural schools is still illustrating a so-called traditional teaching method which is generally based on teachers' talking, textbook-based teaching, chalk and board, grammar and spellingfocused exams at the end of each year. As a result, ethnic minorities students become passive learners and the classroom atmosphere is boring. An attractive learning environment to motivate student to learn should start from the use of natural condition in rural school to create an open learning environment. If the urban and city schools have very limited of space, the rural schools are the featured with open space and fresh air and green trees. These are the special advantages of rural school which should be used to build different English learning situations. Optimising the use of these outside-classroom space for the English learning process will help students to be more confident and willing to learn as well as reduce their stress and boost their confidence (Montessori, M., 1964). As rural students are familiar with the outside natural world more than the small classroom, learning English in the nature would help the students learn the language in more interactive, effective and creative ways. As in our real life, it is important to let the students to experiment, learn from their own mistakes and putting themselves in any communicative situations as the main purpose of language learning is to communicate effectively (Montessori, M., 1964).

An attractive learning environment also comes with a variety of activities by using different teaching aids available, realias, games and competitions to generate continuous learning environment which encourage students to learn every day. An attractive learning environment is a place where students can learn English by setting up the classes and outdoor spaces as in many situations in real life of local people in combination with some typical activities and different daily activities and festivals from other parts of the country as well as the world to help students discover, learn and understand new cultural aspects. The key factor to create an attractive learning environment is the understanding of the learners' level, so that teachers can select the key knowledge and language to simply teach students by putting them in stress-free real-life interactions and contexts where students can do, play and learn by themselves. With a variety of learning activities, an attractive learning environment will be suitable for a variety of students' learning styles.

Thirdly, always starting from simple things: It is a matter of fact that many teachers in rural areas rush their teaching to cover up the curriculum. There is nothing wrong with following the textbook and curriculum; however, 
to ensure the quality of teaching, teachers must base on students' level to decide the teaching methodologies and techniques as well as to choose the appropriate amount of language and knowledge to teach rural students.

Starting from simple is the key factor to keep student motivated in learning. Simple can be defined as easy - to understand language as well as familiar activities in rural students' life which they feel free to take part in and use the language. The simple language can be the one related to every day life of rural students, simple sentences and most common vocabulary, structure. Simple also means the learning process of using these languages is simply happen through daily activities, conversations without stressing on learning time, or the correction of the usage and pronunciation of the words. Simple does not mean insufficient or superficial but referring more to using more practical languages and increasing the time to practice the most basic language to help students to be more confident and not afraid of making mistakes. As rural students are very vulnerable, simple also mean the ways teachers behave and talk to students should be gentle, respectful and friendly. As the result, this approach will strengthen students' confidence to use the language in communication and raising their voice in the target language without the inference of the fear of making mistake. This is crucial for every single student to freely use the language to express their thoughts and ideas. Forcing production in a second language causes many learners to become anxious, resulting in frustration and poor performance.

Fourthly, the role of teachers: Teacher has been considered one of the most influential factors in motivating learners to learn English, especially in the rural schools where students have no opportunities to go to any English centre. English teachers are not only the model of the language, but they are also the people who inspire or motivate students to learn English. To motivate learners, teachers need to provide a wide range of "comprehensible input" which is related to routine classroom activities with different sources of information and interesting knowledge. In addition, they need to generate opportunities for students to practice words, phrases, and sentences which are used in different situations outside classroom so that students can acquire the language form different resources. Moreover, teachers should create an pressure-free learning environment where there is very low-anxiety atmosphere to make sure that students can naturally and happily learn English as the learning outcome highly depends on the attitudes, characters, proficiency, behaviours, methodologies and techniques, the teaching styles, and the ability to communicate and organise the learning environment of teachers.

To motivate students to learn English, teachers need to have different linguistic skills to deliver the contents with friendly classroom atmosphere and understanding of learners' psychological characteristics as well as the proficiency of English. With the ability to speak fluent English as native speaker of English, teacher will create a first great impression on students and more likely to inspire them to study English. Moreover, the ability to create a funny, relaxing learning environment with the effective use of body languages, voice tone, intonation and realias will also attract students to focus on learning without any stress and anxiety. Students will also be more motivated in learning if teachers can provide them with suitable and fair feedbacks by means of supporting, giving opportunities to do things and raise their voice as well as making eye-contact during the lessons. Most importantly, the ways teachers communicate with students will be the key to motivate or demotivate students to study. Teachers need to show their respect to the students by talking, sharing, and understanding of their strengths and weaknesses as well as their difficulties in life; providing students motivating feedback but always evaluate them fairly is also important to keep students motivated. Rural students can be demotivated by a very simple actions which make them feel unhappy.

In the globalisation era, smart phones have become the basic equipment for most people including rural students. Most of them have their own smart phones with modern functions. Therefore, optimising the use of technologies is very important in language learning and teaching. Technologies always bring people up-to-date information, inspiration to discover and even addiction. Using effective technologies will be the best way to enhance teaching and learning progress. Based on the condition of each rural school, teacher should optimise the use of technologies available with the specific condition of nature, space, and other equipment to create effective and attractive learning environment. In addition, using and asking student to use technologies in learning such as PowerPoints, videos, audios, pictures, and social media, is obviously important to motivate students to learn English and to provide a variety of learning options for students. However, the most important factor is still the understanding of students' level so that teachers know what they should focus on to help students study better, and how to help them to be more confident and active in their learning. 


\section{DISCUSSION AND CONCLUSION}

It is clear that motivating students to learn English involves a variety of theories and practices. However, it is obvious that motivation is the key for students to study English effectively. To motivate them to study is to make them understand the significant role of English in their life, their future as well as for the community and the whole nation. In addition, it is important to understand their level of English, their real ability in order to provide the most suitable teaching techniques to make them feel confident in learning. Creating the open, attractive and supportive learning environment with the use of a variety of learning resources, especially the optimization of using natural spaces and cultural context to make English become familiar with rural students' life and perception will also improve the quality of teaching and learning. There is no doubt to say that teachers hold the key role to motivate students to study as they will be the ones who support students to make all the learning process happen. To do this, teachers also need to continuously learn to improve their language competencies, listening to their students, sharing their happiness and sadness and discovering English as a significant part of their daily life with their students.

\section{REFERENCES}

Adara, R. A. (2018). Students' motivation and preferences toward native and non native English speaking teachers. Premise Journal, 7(1), 1-21.

Cynthia, W., \& Pham, C. (2017). Time in the experience of agency and emotion in English language learning in rural Vietnam. Innovation in Language Learning and Teaching, 11(3), 207-218.

Dörnyei, Z. (2001). New themes and approaches in second language motivation research. Annual Review of Applied Linguistics, 21, 43-59.

Dörnyei, Z., \& Ottó, I. (1998). Motivation in action: A process model of L2 motivation. Working Papers in Applied Linguistics (Thames Valley University, London), 4(43-69).

Gardner, R. C. (2005). Integrative motivation and second language acquisition. (Joint Plenary Talk), Canadian Association of Applied Linguistics/Canadian Linguistics Association.

Gardner, R. C., \& Lambert, W. (1972). Attitudes and motivation in secondary language learning. Rowley: Newbury House.

Hamidah, A. R., Azizah, R., Shah, R. A. W., Faizah, M. N., Wan, Z. W. Z., \& Mohd, A. B. (2017). Factors affecting motivation in language learning. International Journal of Information and Education Technology, 7(7), 543-547.

Pham, T. T. H. (2010). Factors affecting the motivation of Vietnamese technical English majors in their English study. University of Otago, New Zealand.

Vi, V. H. (2017). How to motivate and sustain learners' interest in learning English at school. Vietnam Journal of Education, special edition, 182-184.

Kimura, Y., Nakata, Y., \& Okumura, T. (2001). Language learning motivation of EFL learners in Japan - A crosssectional analysis of various learning milieus. Japan Association for Language Teaching, 23(1), 48-68.

Mehr, R. (2010). The role of motivation in language learning. Dialog on Language Instruction, 21(1-2), 1-10.

Montessori, M. (1964). The Montessori Method. USA: Robert Bentley.

Oxford, R. L. (2003). Language learning styles and strategies: Concepts and relationships. IRAL International Review of Applied Linguistics in Language Teaching, 41(2), La Oxford, Rebecca L IRAL; 2003; 2041, 2004; ProQuest pg. 2271.

Pınar, Y. K., \& Kurt, H. (2018). Instructional practices that motivate students to learn English. Journal of Education and Future, 14, 119-130.

Richard, M. R. \& Deci, E. L. (2000). Intrinsic and extrinsic motivations: Classic definitions and new direction. Contemporary Educational Psychology, 25, 54-67.

Trang, N. T. T. (2012). English language policies for Vietnamese primary schools and issues of implementation in rural and mountainous areas. The Journal of Asia TEFL Special Issue, 115-134.

Yoko, K., \& Steven, J. R. (2011). Contextual dynamics in foreign language learning motivation. Language Learning, 61(4), 1328-1354. 